\title{
IMPROVING STUDENTS' READING COMPREHENSION ON NARRATIVE TEXTS THROUGH EXPERIENCE TEXT RELATIONSHIP (ETR) METHOD AT SMA SWASTA PALAPA MEDAN IN THE ACADEMIC YEAR OF 2020/2021
}

\author{
Yatafati Lahagu, Jontra Jusat Pangaribuan, Meikardo Samuel Prayuda \\ Catholic University of Saint Thomas \\ Email : jontra_pangaribuan@ust.ac.id
}

\begin{abstract}
This research was conducted in order to improve students' Reading Comprehension on Narrative Texts through ETR method and to know the students' responses towards the learning reading comprehension through ETR method at SMA Swasta Palapa Medan. In conducting this research, the writer used Classroom Action Research (CAR). This research showed that teaching reading comprehension through ETR method at SMA Swasta Palapa Medan could improve their reading comprehension. The result of the test showed that the students' mean score in pretest is 51.59 with 4 students $(13,79 \%)$ of the students got score $\geq 70$, in formative test the mean score is 68.69 with 15 students $(51,72 \%)$ of the students got score $\geq 70$, and in post-test the mean score is 77.66 with 21 students $(72,41 \%)$ of the students got score $\geq 70$. The writer concluded that ETR method could improve the eleventh grade students' reading comprehension on narrative texts of SMA Swasta Palapa Medan. On the other hand, the students' responses towards the method of the teaching sound good because above $80 \%$ of the students are interested, motivated and understand the lesson with the ETR method.

Keywords: Experience Text Relationship (ETR) Method, Reading Comprehension
\end{abstract}

\section{INTRODUCTION}

Reading is one of the four basic skills in learning English besides listening, speaking, and writing. Reading is one of the most important skills that must be mastered by the students in learning English besides other skills. Through reading, students can get much knowledge and information from books, magazines, newspapers, and others. Therefore, having good reading comprehension is a must for a student. Pang et al. (2003:6) states that reading is about understanding written texts. It is complex activity that involves both perception and thought. Reading consists of two relates processes: word recognition and comprehension. They also say that readers typically make use of background knowledge, grammatical knowledge, experience with text and other strategies to help them understand written text.

From the definition above, the writer concludes that reading comprehension is an interactive process between reader and text to comprehend the writer's message. The reader uses their prior knowledge to develop and understanding the new information from the text.

I made an interview to the English teacher at SMA Swasta Palapa Medan on Saturday, $25^{\text {th }}$ July 2020, the writer interviewed Ma'am T. Ambarita, S. Pd, about the students' reading comprehension. She said that the students were lack of comprehending reading texts and they are always confused when they are reading English texts. There were some facts indicating the problems. First, the students' 
interest of reading was still low. Second, the students had difficulties in comprehending a text. They got difficulty in understanding sentence, and finding the meaning of the sentences.

The problem above should be immediately solved. Teachers have to consider a method to solve the students' problem in order to have good reading comprehension. Regarding the situation, the writer will apply Experience Text Relationship (henceforth, ETR) method to improve the students' reading comprehension. Carrell et al. (1989:654) state that ETR method emphasizes comprehension in reading for meaning. ETR method is one of the best methods in teaching reading comprehension, besides Reciprocal Teaching Strategy, SQ3R Method, Semantic Mapping, K-W-L strategy, and etc.

The writer chooses ETR method because some researchers have shown good result of teaching English reading comprehension through ETR method. The first researcher was carried out by Samosir et al. (2013) entitled "Improving Students' Reading Comprehension Achievement in Narrative Text through Experience- Text- Relationship (ETR) Method. The method of this research was classroom action research which was done in 6 meetings. The subject of this research was the second grade of SMP N 41 Medan with total number of students 34. The research instrument were the reading test, observation sheet, and diary notes. The findings of this study indicated that ETR Method could improve the students' reading comprehension achievement. The students' mean score in pretest is 64,38 . After ETR method was applied, the students' mean score in posttest became 77, 20.

The second one was carried out by Pramanik (2015) entitled "The Implementation of the Experience-Text Relationship (ETR) Method to Improve Grade VIII Students' Reading Comprehension at SMP N 9 Yogyakarta in the Academic Year of 2014/2015". It had been statistically proven by the increase of the students' mean score in post-test which is higher than the mean score in pretest. In the pre-test, the students' average score is 66,52 and in the post-test students' average is 77,41 . She concluded that there are three advantages of ETR method. Firstly, the method was able to change students' attitude and behavior towards reading lesson seen from students' interest and enthusiasm which increased. Secondly, the method was able to increase students' participation in the class discussion. Lastly, the method was able to give the students' opportunity in attempt to achieve reading goals.

Considering the result of the researchers above, the writer is interested to conduct same method of teaching to improve students' reading comprehension of SMA Swasta Palapa Medan in the Academic Year of 2020/2021. Based on the background of the study, the writer decided to conduct a research entitled 'Improving Students' Reading Comprehension on Narrative Texts through Experience Text Relationship (ETR) Method at SMA Swasta Palapa Medan in the Academic Year of 2020/2021".

\section{REVIEW OF LITERATURE Reading}

Reading is a number of interactive processes between the reader and the text, in which readers use their knowledge to build, to create, and to construct meaning. Afflerbach (2018:25) states that reading is a dynamic and complex 
process that involves strategy, skill, and prior knowledge. Readers typically make use of background knowledge, vocabulary, grammatical knowledge, experience with text and other strategies to help them understand written text.

Reading is the act of constructing meaning while transacting with text in the process of reading, the reader interacts dynamically with the text. Roe and Smith (2012:24) state that reading involves the construction of the meaning represented by the printed symbols. Reading is not to be a passive activity but reading is an active process in which readers relate information in the text to what they already know. It is the way how to the reader tries to get the message or the intended meaning from the writer.

In addition, Grabe and Stoller (2020:5) state that reading is the ability to draw information from the text and interpret that information coherently. In other words, reading is the ability to comprehend the text. From the explanations above, it can be concluded that reading is a dynamic and complex process in which interaction between a reader and a text is occurred in order to extract information from the text, and in the process of extracting information, the reader needs to make use of their prior knowledge and they relate it to the content of text to form an interpretation of information from the text.

\section{Types of Reading} as follow:

Patel and Jain (2008:117) state that there are four types of reading, those are

\section{a. Intensive Reading}

Intensive reading is related to further progress in language learning under the teacher's guidance. Intensive reading will provide a basis for explaining difficulties of structure and for extending knowledge of vocabulary and idioms. It will also provide material for developing greater control of the language in speech and writing. It means that intensive reading is done to get specific information. The goal of this reading is active use of language.

b. Extensive Reading

Extensive reading is used to obtain a general understanding of a subject and includes reading longer texts. The reader may read novels, magazines, newspapers or other reference materials. It can be called reading for pleasure or joyful reading. The purpose of extensive reading will be to train the students to read directly and fluently in the target language. Through this reading, the good reading habit can be developed.

c. Aloud Reading

Aloud reading is type of reading engaged the eyes to read and the brain to understand content of the text. The aim of reading aloud will be to train the student to develop their skill of pronunciation very well.

d. Silent Reading

Silent reading is type of reading not necessary to make sound and to move lips. So, it is only involve understanding the text by looking at the text without saying it. Silent reading is able to expand students rapid reading with full understanding.

From those statements, it can be concluded that there are four types in reading. They are intensive, extensive, aloud, and silent reading. Based on those types of reading, the writer knows that intensive, extensive, aloud, and silent 
reading have different meaning. He chose extensive reading in reading comprehension because he gave the longer texts to the students.

\section{The Processes of Reading}

Patel and Jain (2008:114) state that the process of reading may be broadly classified into three stages, those are the recognition stage, structuring stage, interpretation stage. The detail explanation about the process of reading as follows: a. The first stage is the recognition stage. At this stage the learner simply recognizes the graphic cunterparts of the phonological items. For instance he recognizes the spoken words in its written form. Difficulty at this stage depends upon the difference between the script of the learner's mother tongue and English and between the spelling conventions of two languages.

b. The second stage is the structuring stage. The learner sees the syntactic relationship of the items and understands the structural meaning of the syntactical units.

c. The third stage is the interpretation stage. This is the highest level in the process of reading. The learner comprehends the significance of a word, a phrase, or a sentence in the overall context of the discards. For instance, he comprehends the serious and jocular use of words, distinguishes between a statement of fact and a statement of opinion.

From the explanation above, it can be concluded that the processes of reading are started from recognition stage, for instance the students recognizes the spoken words in its written form. in the second stage the students understands the structural meaning of the syntactical units. And in the third stage the students comprehends the significance of a word, a phrase, or a sentence in the overall context.

\section{The Purposes of Reading}

Reading helps students to build their vocabulary, improves students for understanding on written work. By reading, students, will have more experience to elevate their knowledge and their ability in English. Grabe and Stoller (2020:8) state that the purposes of reading are classified into:

1. Reading to Search for Simple Information and Reading to Skim

Most people say that reading search for simple information is a kind of common reading ability in which reader typically scans the text for a specific word. While skimming is reading which is directly go through the reading material quickly in order to get the gist of the text and to get a purpose of the writer.

2. Reading to Learn from Texts

Reading to learn typically occurs in academic and professional contexts in which a person needs to learn a considerable amount of information from the text. Reading to learn is usually carried out at a reading rate somewhat slower than general reading comprehension. In addition, it makes stronger inferencing demands than general comprehension to connect text information with background knowledge.

3. Reading to Integrate Information, Write, and Critique Texts

Reading to integrate information requires additional decisions about the relative importance of complementary, mutually supporting, or conflicting information and the likely restructuring of a rhetorical frame to accommodate 
information from multiple sources. Both reading to write and reading to critique text requires abilities to compose, select and critique information from a text.

4. Reading for General Comprehension

Reading for general comprehension is the most basic purpose for reading. requires very rapid and automatic processing of words, strong skills in forming a general meaning representation of main ideas, and efficient coordination of many processes under very limited time constraints.

From the explanation above, it can be concluded that people read something because they have a desire to do or a purpose to achieve. They may read a text to search for simple information and to skim, reading to learn from texts, reading for general comprehension, reading to integrate information, write, and critique texts.

\section{Reading Comprehension}

The main purpose of reading is comprehension. Pang et al. (2003:14) state that reading comprehension is the process of deriving meaning from connected text. It involves word knowledge as well as thinking and reasoning. Therefore, comprehension is not a passive process, but an active one. The reader actively engages with the text to construct meaning. This active engagement includes making use of prior knowledge.

Klingner et al. (2007:8) state that reading comprehension is a complex process involving interaction of many components. Reading comprehension is the process of constructing meaning by coordinating a number of complex processes that include word reading, word and word knowledge and fluency. It means that reading comprehension is activity the readers when they read to understand and to get total meaning of the passage.

Snow (2002:11) states that reading comprehension as the process of simultaneously extracting and constructing meaning through interaction and involvement with written language. The process of constructing meaning is the process in which the reader combines their prior knowledge with the additional information from a text, draws the meaning of words, and they connect it to reach the clear understanding of the written text.

From the definitions above, it can be concluded that reading comprehension is the complex process involving interaction of many components, in which the readers construct meaning from a text, and they connects it to the background knowledge they have to get the clear understanding of writer's message.

\section{The Levels of Reading Comprehension}

Reading comprehension is considered to occur at four levels of complexity. According to Burns, Roe and Ross (1984:177) state that levels of reading comprehension are literal level, interpretative level, critical level and creative level. Consider the following brief passage:

1) Literal Comprehension

Literal comprehension involves acquiring information that is directly stated, the basic of literal comprehension is recognizing the stated main idea, detailed caused effect and sequence. It is also prerequisite for higher-level understanding. The important in this level is understanding vocabulary, sentence meaning, and paragraph meaning.

2) Interpretative Comprehension

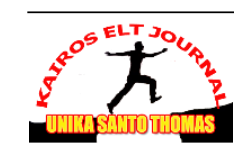


Interpretative comprehension involves reading between the lines or making inferences. It is the process of deriving ideas that are implied rather than directly stated. Skills for interpretative reading include: inferring main idea of passages in which the main idea are not directly stated, inferring cause-effect relationship when they are not directly stated, inferring referents of pronouns, inferring referent of adverbs, inferring omitted words, detecting mood, detecting the author's purpose in writing, drawing conclusion.

3) Critical Comprehension

Critical comprehension is evaluating written material comparing the ideas discovered in the material with known standards and drawing conclusion about their accuracy, appropriateness, and timeliness. The critical reader must be an active reader, questioning, searching for facts, and suspending judgment until he or she considered all of material. Critical reading depends upon literal comprehension, and grasping implied ideas is especially important.

4) Creative Comprehension

Creative comprehension involves going beyond the material presented by the author. It requires reader to think as they read, just as critical reading does and it also requires them to use imaginations. Through creative reading the reader creates something new idea, solution to a problem, a new way of looking at something from the ideas gleaned from the text.

Based on the levels of reading above, literal level, Interpretative level, critical level, and creative level are interconnected. It means, in reading comprehension students must be able master the first level until the fourth level. In this study I will choose critical comprehension in reading comprehension.

\section{The Processes of Reading Comprehension}

Grabe and Stoller (2020:27) state that reading comprehension is an extraordinary feat of balancing and coordinating many abilities within a very complex and rapid set of processes, allowing us to think that comprehension is an effortless and enjoyable activity for fluent readers. Reading processes occurring every two seconds we read. Roughly, in any two seconds of reading, fluent readers:

1. Focus on and access eight to ten word meanings.

2. Use the grammar context to identify the right word meanings when words have multiple meanings.

3. Parse a clause for information and form a meaning unit.

4. Figure out how to connect a new meaning unit into the growing text model

5. Identify main ideas that emerge from text structure and word signals, or from consistently repeated ideas and information.

6. Use background knowledge, as appropriate, for greater comprehension.

7. Monitor comprehension, recognize instances of non-comprehension, make appropriate inferences as needed, shift strategies and repair misunderstandings, as needed.

\section{Teaching Reading Comprehension}

Teaching reading means teaching to activate prior knowledge about a text. Students must be able to think about what they already know about the text before they read and make connections between ideas after they are finished reading. Brown (2000:7) states that teaching is an activity in which the teacher guides and 
facilititates learning, gives a chance for the learners to learn, and sets the condition for learning. Guidance is done by leading the students to do activities in the effort of getting knowledge.

The teacher can help the students in gaining the knowledge by giving facilities such as tasks. By giving these tasks, the teacher lets the students study by themselves. To make the teaching and learning process run well, the teacher needs to set a good situation for the students to learn. In setting a good condition, the teacher must consider a classroom method or technique that is used as this can influence the way he or she manages the class.

Pang et al. (2003: 14) state that the teacher can lead the learners to understand a text by using some strategies on reading comprehension. The teacher's responsibilities in helping learners achieve these goals is to motivate the students by selecting or creating appropriate texts, to design useful reading tasks, to set up effective classroom procedures, to encourage critical reading, and to create supportive environment for practicing reading.

In addition, Linse (2005:71) states that teaching reading comprehension is teaching students how to derive meaning as well as analyze synthesize what they have read. It means that teaching reading comprehension is a complex activity to make the students comprehend and deepen understanding from what they read on the text.

Based on the definition above, it is concluded that teaching reading comprehension is a complex activity in which the teacher guides the learners on reading comprehension. Guidance is done by the teacher to make the learners reach their reading comprehension on the text using a certain method.

\section{Genres of the Text}

Gerot and peter (1994:190) state that genre can be defined as a culturally specific text-types which results from using language (reading or spoken) to help accomplish something. There are thirteen genres of the text namely:

a. Spoof: The social function is to retell an event with a humorous twist.

b. Recount: The social function is to retell events for the purpose of informing or entertaining.

c. Narrative: The social function is to amuse, entertain, and to deal with actual or vicarious experience in different ways; Narratives deal with problematic events which lead to a crisis or turning point of some kind, which in turn finds a resolution.

d. Procedure: The social function is to describe how something is accomplished through a sequence of action or steps.

e. Anecdote: The social function is to share with others an account of unusual or amusing incident.

f. Hortatory: The social function is to persuade the reader or listener that something should or should not be the case.

g. Explanation: The social function is to explain the processes involved in the information of working of natural or socio cultural phenomena.

h. Description: The social function is to describe how something is accomplished through a sequence of action or steps.

i. Discussion: The social function is to present (at least) two points of view about an issue.

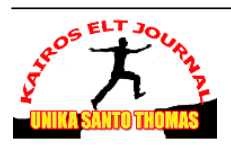


j. Analytical: The social fuction is to persuade the reader or listener something is the case.

k. News item: The social function is to inform readers, listener, or viewers about events of the day which are considered news worthy or important.

1. Reports: The social function is to describe the way thing are with reference to a range of natural, man-mode and social phenomena in our environment.

m. Reviews: The social function is to critique an art work or event for a public audience.

Based on the explanation above, it can be concluded that texts are classified into several types. They are spoof, recount, narrative, procedure, anecdote, hortatory, explanation, description, discussion, analytical, news item, report, and review. This study is focused on narrative text in improving students'reading comprehension as stated in the scope of the study.

\section{Narrative Text}

Narrative text is one of English text types. Narrative text is a text that tells imaginative story in which the purpose in this text is to entertain people. McQuillan (2000:85) states that a narrative text is a story that is told in language; that is, it is convered into language signs. As was evident from the definition of a narrative text, these signs are produced by an agents who relates. This agent cannot be identified with the writer. Rather, the writer with draws and calls upon fictious spokeman, an agent technically known as the narrator.

Anderson and Anderson (1997:8) state that Narrative text is a piece of text which tell a story and in doing so entertain and inform the reader or listener. Meanwhile, (in Permana and Zahri, 2013:2) states that narrative text is a type of essay that tells a story or a series of event in which they occur. In order that text can be enjoyed by the readers, the writer should arrange the text interestingly. The purpose of telling the story is to giving meaning, and to entertain the readers. A narrative text has four parts:

1. Orientation: In this stage, the writer gives the information about the situation of the characters, where they live, the time they live, and what they want. It presents the basic situation which allows the reader to understanding the next parts of story. It may be long or short, according to the writer. It is to be the opening or introduction.

2. Complication: It is where something unexpected happen or events go wrong for one of the main characters in the story. There can be more than one complication events in narrative text. Here, the author shows how the problems rises or begin.

3. Resolution: It is the solution of the problems or when the crisis is resolved, for better or worse.

4. Coda: It is moral value or lesson which can be taken from the text.

From the statement above, it is concluded that a narrative text is a text which contains a story ordered chronologically that is orientation, evaluation, complication, resolution and coda. Narrative is spoken written text to communicate a massage, which is used to interpret it is meaning in the story and to entertain the readers. 


\section{Characteristics of Narrative Text}

1. Past tense: it is used to tell situation in the the past. (e.g killed, drunk, etc)

2. Adverb of time: it is tell when something happened and how long something lasted or lasts (e.g Once upun a time, one day, etc)

3. Time conjunction: it is used to connect words or sentences (e.g when, then, suddenly, etc)

4. Specific character: The character of the story is specific, not general. (Cinderella, Snow White, Alibaba, etc)

5. Action verbs: A verb that shows an action. (e.g killed, dug, walked, etc)

6. Direct speech: It is to make the story lively. (Snow White said,"My name is Snow White). The direct speech uses present tense.

The example of Narrative Text

\begin{tabular}{|l|l|}
\hline Title & Cinderella \\
\hline Orientation & $\begin{array}{l}\text { Once upon time, there was a beautiful girl called } \\
\text { Cinderella. She lived with her stepsisters and stepmother. } \\
\text { They were very bossy. She had to do all the housework. }\end{array}$ \\
\hline Complication & $\begin{array}{l}\text { One day an invitation to the ball came to the family. Her } \\
\text { stepsisters did not let her go, so Cinderella was very sad. } \\
\text { The stepsisters went to the ball without her. }\end{array}$ \\
\hline Resolution & $\begin{array}{l}\text { Fortunately, the good fairly came and helped her to get to } \\
\text { the ball. At the ball, Cinderella danced with the prince. The } \\
\text { prince felt in love with her then he married her. They live } \\
\text { happily ever after. }\end{array}$ \\
\hline Coda & $\begin{array}{l}\text { forgiving others for doing wrong, and never letting bad } \\
\text { things ruin your heart. }\end{array}$ \\
\hline
\end{tabular}

\section{ETR METHOD}

ETR Method is a method of teaching. It is a kind of metacognitive strategy that can be applied in teaching reading comprehension. Beside of the ETR method, there are also some methods or strategies that are often used in improving students' reading comprehension, such as: Reciprocal teaching strategy, Directed -ReadingThinking- Activity (DRTA), SQ3R, K-W-L strategy, and etc.

The ETR method draws on English language learners' background knowledge and experience. This method can run well when the students have adequate background knowledge relate to the story that will be read. Lawrence (2007:59) states that in ETR method, building prior knowledge needs to be the focus in the teaching and learning process. In order to comprehend reading text, English learners are required to firstly active their background knowledge.

Medina (2012: 83) states that ETR method helps learners to active and develop their background knowledge of the text. It can help the students to activate their background of knowledge in drawing the meaning of a text or story. Then, they relate it to the new information that they have got from the text after reading process. Furthermore, Griffin et al. (2013:184) state that ETR method is emphasize tying learners' own experience with text cues to arrive at meaning.

Based on the experts' opinion above, it can be concluded that ETR method is a method can be used in teaching reading that help teacher to monitor the students in expressing their own experiences and guide them to relate their own experiences 
to text provided in drawing the meaning of a text. It means ETR method helps students understand the content of the text by connecting the experience that the students have.

As its name, this method consist of three stages. They are experience stage, text stage and relationship stage. Lawrence (2007:59) states that ETR method has three basic steps can be applied in the classroom as follows:

1. The experience step: for pre reading, the students discuss their personal experiences that relate to the theme, topic, or main idea of the text to be read. Then the students generate predictions about the story.

2. The text step: The students read a section of the story to check the predictions. while reading, either read the text aloud as the students follow along or allow students to read silently on their own. Read only one section of the story at a time. Discuss the section read and confirm and change predictions. Make sure that students tie their thoughts, comments, and predictions back to the text.

3. The relationship step: for post reading, the teacher help students integrate the information from the text with their experiences to develop an understanding of the text.

\section{The Advantages of ETR Method}

1. The activation and use of background knowledge in ETR method is really helpful for the students to improve their comprehension.

2. ETR method provides opportunities for the students to explore many dimension of story and integrate feature of it with their existing knowledge.

3. Guiding questions given to build students' prior knowledge can create motivating reading environment.

4. Answering any question related to the story gives the students practice in formulating and expre ssing complex thoughts.

5. In ETR method teacher can systematically guide the reading process and monitor students' reading comprehension.

\section{RESEARCH METHOD}

\section{The Research Design}

This research is Classroom Action Research (henceforth, CAR) which using ETR Method in teaching reading class. Burns (2010:5) states, "Action research is research carried out in the classroom by the teacher of the course, mainly with the purpose of solving a problem or improving the teaching/learning process". It means that the writer must be have the solution to solve the students' problem and gives the improvement in the teaching process in the classroom.

In the classroom action research teacher apply a method or technique in teaching and learning process to improve students' achievement. Mettetal (2001:8) states that CAR is a method of finding out what works best in teacher own classroom so that she or he can improve student learning. It means classroom action research is the method or way of teacher to solve the problem of students when they follow teaching learning.

Winter and Giddings (2001:8) state that action research is the study of a social situation carried out by those involved in that situation in order to improve both their practice and the quality of their understanding. It means that in teaching 
learning, they need socialization each other to develop their knowledge through practice.

From the definitions above, it can be concluded that CAR is an action research in a classroom which can be done by teachers, and researchers, etc which involves a group of students. Mainly with the purpose of solving the students' problem by applying a method or technique to improve teaching and learning process or to enhance the understanding of the students to the lesson.

\section{The Location and Time of the Study}

The study would be conducted at SMA Swasta Palapa Medan which is located on Jln. Bunga Lau No. 09 Medan Tuntungan. There were two reasons why the writer chooses the school as the location of the research. Firstly, based on the preliminary research that was done by the writer, it is needed to improve students' reading comprehension of the eleventh grade students of SMA Swasta Palapa Medan in the Acdemic Year of 2020/2021 through ETR method. Secondly, there have never been other researchers who conduct the same study before at the school. This study would be conducted in August 2020.

\section{The Subject of the Study}

The subject of this study was the eleventh grade students of SMA Swasta Palapa Medan in the Acdemic Year of 2020/2021. There were two classes of the eleventh grade students which consist of class XI-MIPA, XI-IPS. However, the writer took only one class as the subject of the study. The subject of the study is class XI-IPS which consists of 29 students, consisting of 17 female students and 12 male students.

\section{The instruments of Data Collection}

Arikunto (2002: 126) states, "There are many technique that can be used to collect data. They are test, interview, observation, questionnaire, and documentation". The instruments which are used in order to collect the data in this study are test, observation sheets, questionnaire, and field notes.

\section{The Procedures of Classroom Action Research}

The writer uses CAR in conducting the research. The CAR model used by the writer is developed by Kemmis and Mc. Taggart. This CAR is arranged into two cycles. They are cycle one and cycle two. Kemmis and McTaggart in Burns (2010: 7) state that action research typically involves four broad phases in a cycle of research. The four phases in a cycle are: (1) planning, (2) action, (3) observation, and (4) reflection.

\section{DATA ANALYSIS AND DISCUSSION Data Analysis}

The data of this research was collected from the eleventh grade students of SMA Swasta Palapa Medan in the Academic Year of 2020/2021. In the data analysis, there are two types of data which were analyzed to find out the result and students' responses towards learning teaching process of reading comprehension on narrative texts by using ETR Method. Namely qualitative and quantitative. The quantitative data were taken from the result of pre-test, formative test, and post-test. 
The qualitative data were taken from observation sheet, questionnaire and field notes.

\section{Discussion}

ETR method was applied to improve students' reading comprehension to the eleventh grade students of SMA Swasta Palapa Medan. Before applying ETR method in teaching reading the writer analyzed the most of the students did not pay attention to their teacher. The result of the pre-test also showed that the students' score were not satisfying. Only 4 students of 29 students passed the Mastery Minimum Criteria (Kriteria Ketuntasan Minimum).

This research has proved that ETR method is effective to improve students' reading comprehension. It is shown in the students' score from pre-test, formative test until post-test. The students' reading comprehension on narrative text improved after ETR method was applied in learning teaching processes. It happens because this method activate students' prior knowledge, so they easier to learn narrative text.

\section{CONCLUSIONS AND SUGGESTIONS Conclusion}

After analyzing and discussing the data, the writer draws the following conclusions as follows:

1. ETR method could improve students' achievement in increased students' reading comprehension. The students' mean score of pre-test is 51.59 , formative test is 68.69 and post-test is 77.66. Meanwhile, the students score percentage who passed Mastery Minimum Criteria (Kriteria Ketuntasan Minimum) from pre-test is $13,79 \%$, the formative test is $51,72 \%$ and post-test is $72,41 \%$. The students' score and percentage continuously increased each test. Therefore, it is concluded that ETR method could improve the students' achievement in reading comprehension.

2. The students' responses in teaching reading comprehension on narrative texts are categorized effective. It can be seen from the table that the students questionnaires in learning teaching process using ETR method. 25 students (86\%) were interested, it means that they interested teaching learning process by using ETR method. There are 26 students (90\%) who understand, it means that they understand the material that is taught by the teacher easily. 25 students (86\%) said that the teacher did comprehend the learning material. 24 students $(83 \%)$ were motivated, it means that they motivated in reading by using ETR method. And there are 26 students $(90 \%)$ who got better score in reading after they were taught by the teacher with ETR method.

\section{Suggestions}

In this part, the writer would like to give some suggestions as follows:

1. The English teachers should be more active and innovative in applying ETR method in order to maximize teaching reading comprehension. Thus, the students become active and interested in learning English, especially in learning reading comprehension,

2. The students should pay attention to the rules how to improve their reading comprehension through ETR method.

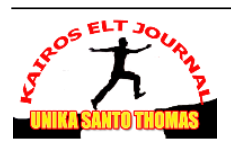


3. The other writers, the result of this study is expected to be able to provide valuable information how to improve students' reading comprehension through ETR method.

\section{BIBLIOGRAPHY}

Afflerbach, P. 2018. Understanding and Using Reading Assessement, K-12 (3 ${ }^{\text {rd }}$ Ed.) Alexandra: ASCD.

Anderson, M., and Anderson, K. 1997. Text Types in English. Sidney: Macmilan Education Australia. PTY. LTD.

Arikunto, S. 2002. Prosedur Penelitian Suatu Pendekatan Praktik (Edisi Revisi V). Jakarta: Rineka Cipta.

Best, J. N., and Khan, J. V. 2002. Research in Education. New Delhi: Prentice Hall of India.

Brown, H. D. 2000. Principles of Language Learning and Teaching. New York: Longman.

2004. Language Assessment: Principles and Classroom Practices. New York: Pearson Education.

Burns, P. C., Roe, B. D., and Ross, E. P. 1984. Teaching Reading in Today's Elementary Schools ( $3^{\text {rd }} \mathrm{Ed}$ ). Boston: Houghton Mifflin Company.

2010. Doing Action Research in English Language Teaching: A Guide for Practitioners. London: Routledge.

Carrell, P. L, et al. 1989. Metacognitive Strategy Training for ESL Reading. Journal of Tesol Quarterly, 23(4), 647-675.

Gerot, L., and Peter, W. 1994. Making Sense of Functional Grammar. Gerd stabler :Sydney.

Grabe, W., and Stoller, F. L. 2020. Teaching and Researching Reading ( ${ }^{\text {rd }}$ Ed). New York: Routledge.

Klingner, J. K, et al. 2007. Teaching Reading Comprehension to Students with Learning Difficulties. New York: The Guide for Press.

Lawrence, L. J. 2007. Teaching Reading to Children. New York. Cognitive And Metacognitive Reading Strategies Revisited: Implications for Instruction. The Reading Matrix, 7(3), 55-71. 
Linse, C. T. 2005. Practical English Language Teaching: Young Learners. New York: McGraw-Hill Companies, Inc.

McQuillan, M. 2000. The Narrative Reader. London: Routledge.

Medina, S. L. 2012. Effects of Strategy Instruction in an EFL Reading Comprehension Course: A Case Study. Journal of Universidad Nacional de Colombia, Facultad de Ciencias Humanas, Departamento de Lenguas Extranjeras, 14(1), 79-89.

Mettetal, G. 2001. The What, Why and How of Classroom Action Research. The Journal of Scholarship of Teaching and Learning (JoSoTL). 2(1), 8.

Pang, S, et al. 2003. Teaching Reading: Educational Practices Series. France: Sadag, Bellegarde.

Patel, M. F., and Jain, P. M. 2008. English Language Teaching (Methods, Tools \& Techniques). Jaipur: Sunrise Publisher \& Distributor.

Permana, T. D., and Zuhri, F. 2013. The implementation of Pictures Series as Media in Teaching Writing of Narrative Text of the Tenth Grades of Senior high School. Journal of Retain, 1(1), 1-8.

Pramanik, C. D. 2015. The Implementation of the Experience-Text Relationship (ETR) Method to Improve Grade VIII Students' Reading Comprehension at SMP N 9 Yogyakarta in the Academic Year of 2014/2015. An Unpublished Sarjana's Thesis, Faculty of Languages And Arts: State University of Yogyakarta.

Roe, B. D., and Smith, S. H. 2012. Teaching Reading in Today's Elementary Schools $\left(11^{\text {th }} \mathrm{Ed}\right)$. Belmont: Cengage Learning.

Samosir, D. N., and Meisuri. 2013. Improving Students' Reading Comprehension Achievement in Narrative Text through Experience- Text- Relationship (ETR) Method. Journal of English Language Teaching and Learning of FBS UNIMED, 2(2), 1-14.

Snow, C. C. 2002. Reading for Understanding towards An $R \&$ \& Program in Reading Comprehension. Santa Monica: RAND.

Thomas, R. M. 2003. Blending Qualitative and Quantitative Research Methods in Theses and Dissertations. California: Corwin Press.

Winter, R., and Giddings, C. 2001. A Handbook for Action Research in Health and Social Care. New York: Routledge. 